\title{
EVIDENCE FOR THE DEVELOPMENT OF ENERGY RESILIENCE IN FUKUSHIMA PREFECTURE AFTER THE GREAT EAST JAPAN EARTHQUAKE
}

\author{
R. Cong ${ }^{1, *}, \mathrm{~K}$. Gomi ${ }^{1}$ \\ ${ }^{1}$ Fukushima Branch, National Institute for Environmental Studies, 9637700 Tamura District, Japan \\ richao.cong@nies.go.jp
}

Commission IV

KEY WORDS: Before and after, Energy resilience, Fukushima nuclear disaster, GIS, Spatial analysis, Sustainable development

\begin{abstract}
:
Taking the lessons from the Great East Japan Earthquake (GEJE) occurred in March 2011, the nuclear-reliant energy policy in Fukushima Prefecture has been transformed to other energy (fossil fuel, renewable energy) to make their energy system with better resilience toward the future disaster. As the increased concern on the Global Warming, Fukushima Prefecture made more efforts on the promotions of the renewable energy than the fossil fuel power. Nine years has passed since the GEJE, however, the spatial variation of the energy supply facilities is not clarified and the resilience of its energy system has not been evaluated. Therefore, this study focused on spatial analysis on these energy supply facilities before and after the GEJE and discussing the energy resilience in Fukushima Prefecture toward future disasters or climate events. This approach will be helpful for policy makers to spatiotemporally evaluate the sustainable development on the energy system.
\end{abstract}

\section{INTRODUCTION}

The Great East Japan Earthquake (GEJE) occurred in March 2011, which led to the tsunami that seriously damaged the infrastructures in Fukushima Prefecture. The Fukushima Daiichi nuclear disaster reinforced the damage and highly impacted the energy policy in Japan.

The biggest impact is the huge drop in the number of nuclear power reactors operating and its share in electricity supply in Japan. The share of nuclear energy was about $25 \%$ before the GEJE in 2010, and it went down to zero in 2014 and still only $6.2 \%$ in 2018 (METI, 2020). Since then, Japanese government started to substitute fossil fuels (FFs) and renewable energy for nuclear power and became more dependent on import and consumption of FFs. As a result, the absolute value of elasticities of oil consumption by some economic sectors to oil prices has reduced after the disaster as the increased dependency on oil consumption, which endangered the energy security in Japan (Taghizaden-Hesary et al., 2017). To decrease the dependency on fossil fuel, the Feed-in Tariff (FIT) scheme of renewable energy was announced and started in July, 2012 (Agency for Natural Resources and Energy, 2012). It is a scheme that make the power companies to buy the renewable energy from the facilities owners at a reasonable price in a period designated by the Japanese government, which is expected to transform the nuclear-reliant energy policy to renewable energy in Japan. The dynamics of the linkages among costs of electricity generation via crude oil, natural gas, and coal for the periods before and after the Fukushima accident were analysed and the result showed changes in Japanese energy policy impacted by this accident (Aruga, 2020).

Taking the lessons from the GEJE, the nuclear power plants in Fukushima have been closed. On the other hand, two large coalfired power plants increased their power generation capacities (Hirono thermal power station $600 \mathrm{MW}$ and Nakoso power plant $250 \mathrm{MW}$ increased in 2013, respectively). To make its energy system more robust, Fukushima Prefecture has started many projects (Fukushima Prefecture, 2013) to promote the development of the renewable energy e.g., Fukushima Prefecture renewable energy promotion vision (2012), Fukushima Airport Mega Solar Project (2014), and Action plan for renewable energy pioneer land version 1-3 (2013 2019). About the renewable energy supply in Fukushima Prefecture, a GIS-based approach has been used to estimate the energy potential, and to hold the energy self-sufficiency analysis for 2020 and 2030 at the regional level (Wang et al., 2014). However, the development and spatial distribution of the entire energy system in Fukushima Prefecture are not clear.

Energy resilience was defined as a range of preparation, absorption, recovery, and adaptation measures that ensure availability, accessibility, affordability, and acceptability of energy supply, transmission and distribution over time (Sharifi et al., 2015). As a concept it purports to serve as a useful indicator of energy system in three stages toward disasters: predisaster e.g., energy security analysis (Hughes et al., 2016), during-disaster e.g., state estimation and real-time information provision (Zhang et al., 2018), and post-disaster e.g., effective rebuilding and recovery (Arab et al., 2016). Energy resilience reflects its ability of an energy system to withstand and recover from extreme climate events and natural disasters. However, it has proved difficult to measure (Molyneaux et al., 2016).

With this background, this study aims to clarify the development and the spatial distribution of FF power and renewable energy facilities before and after the GEJE, and to discuss the energy resilience in Fukushima Prefecture toward future disaster or climate events based on an indicator of the needed operating ratio of power plants. We introduce the study area and the condition of energy system before the GEJE. Then, we show the structure of the current energy system and the

\footnotetext{
* Corresponding author
} 
spatial distribution of the power supply facilities after the GEJE. Finally, we compare the energy system before and after the GEJE, discuss about the development of energy resilience in Fukushima Prefecture since the GEJE, and give conclusions.

\section{METHODOLOGY}

\subsection{Study area and the condition of energy system before the GEJE}

Fukushima Prefecture owns the third-largest area in Japan of $13,783.9 \mathrm{~km}^{2}$ and a population of $1,859,220$ in 2019 (Fukushima Prefecture Government, 2019). As shown in Figure 1, the Fukushima Daiichi Nuclear Power Station (FDNPS) located in the east of Fukushima Prefecture (blue area).

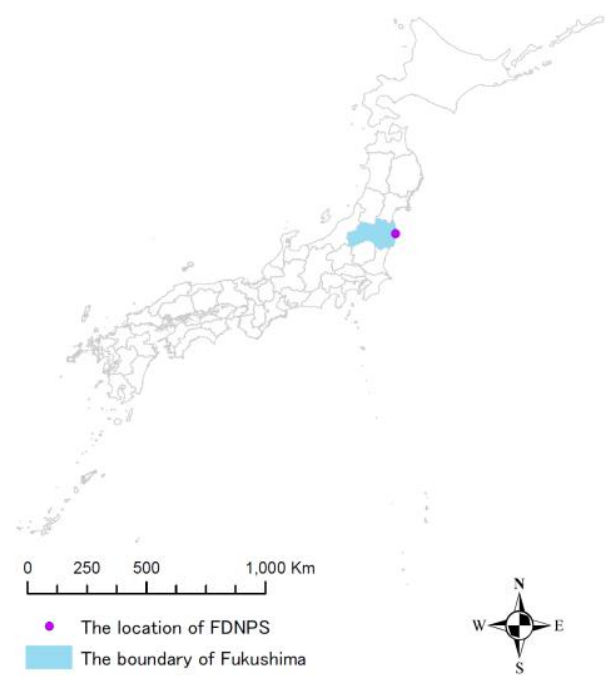

Figure 1. The location of the FDNPS (purple dot) and Fukushima Prefecture in Japan

As shown in Figure 2, the total capacities and the spatial distributions of the power generation facilities in Fukushima in 2010 and 2020 were used to describe the conditions of electricity supply before and after the GEJE and the gridded gap on that between two years were used as evidences to show the development of the energy system. ArcGIS v.10.4 was used to conduct spatial analysis. The facility name, capacity, and locations of these facilities were referred from a database of power plants (Electrical Japan, 2020), and their capacities were updated until 2020 based on the information from the governmental websites.

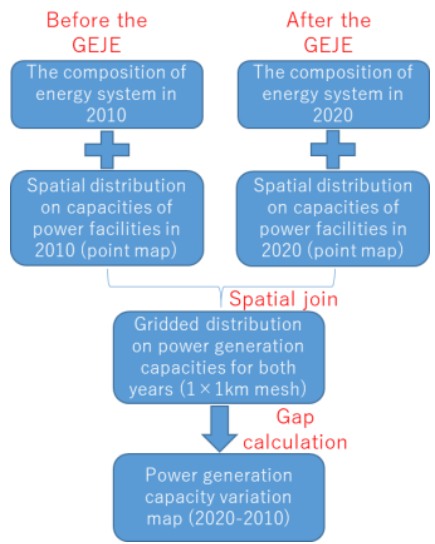

Figure 2. The workflow used to show the evidences on the development of energy system in Fukushima since the GEJE
As shown in Figure 3A, the total capacity of nuclear power in 2010 accounted for the largest proportion of $48 \%$ (9,096 MW), that for FF power was about $40 \%$ (7,493 MW, capacities of the biomass co-fired power were included in this category), and that for the renewable power was about $12 \%(2,213 \mathrm{MW})$. Based on the coordinates taken from google map, the spatial distributions for 231 electricity supply facilities are shown in figure 3B. The number of hydro power facilities is most of all (93). The blue dot with a red star inside shows the plant (FDNPS) with the largest capacity in 2010 (4,696 MW).
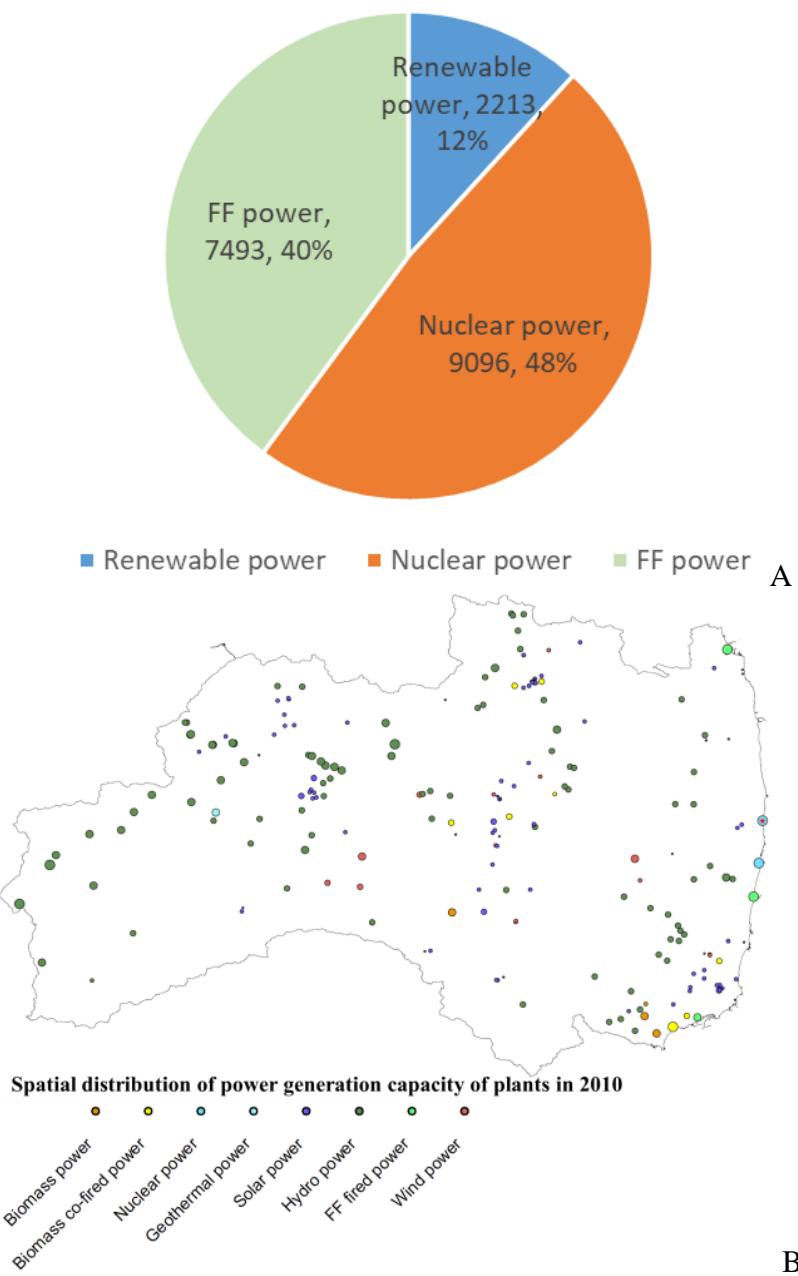

Figure 3. The condition of the electricity supply in 2010 , Fukushima Prefecture: (A), the proportion of the total generation capacity by facility types (unit: MW and \%). Biomass co-fired power plants were classified as FF power; (B), the spatial distribution of the generation capacity of power plants (231). The sizes of dots reflect the capacity of plants and the blue dot with a red star inside shows the plant with the largest capacity

\subsection{The energy condition after the GEJE}

As shown in Figure 4A, the total capacity of FF power in 2020 accounts for the largest proportion of $73 \%$ (9,683 MW, capacities of the biomass co-fired power were included in this category), and that for the renewable power is about $27 \%(3,629$ $\mathrm{MW})$. Due to the impact by the GEJE, all the nuclear power plants in Fukushima have been closed.

The spatial distributions for 625 electricity supply facilities are shown in figure $4 \mathrm{~B}$. The number of solar power facilities is 
most of all (457). The green dot with a red star inside shows the FF fired plant with the largest capacity in 2020 (3,800 MW). Comparing with the figure $3 \mathrm{~B}$, we found the increased facilities since the GEJE mainly located in the middle and eastern areas of Fukushima. As shown in Figure 4C, these plants are mainly concentrated in the municipalities with a higher population.
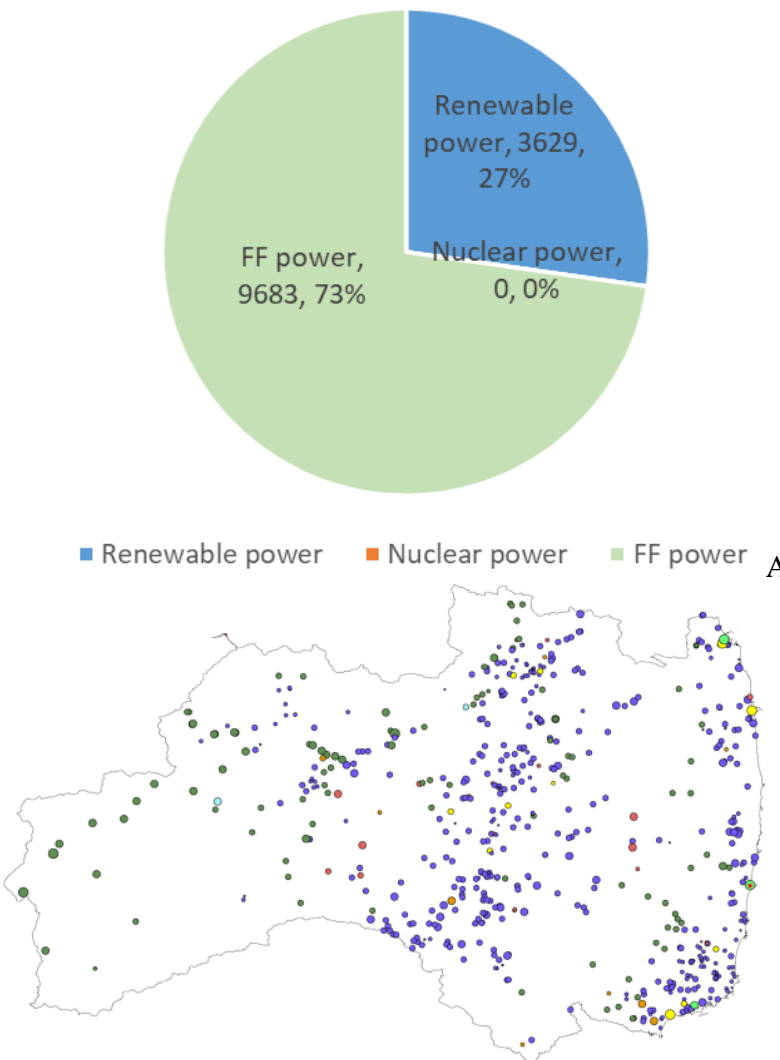

Spatial distribution of power generation capacity of plants in $\mathbf{2 0 2 0}$
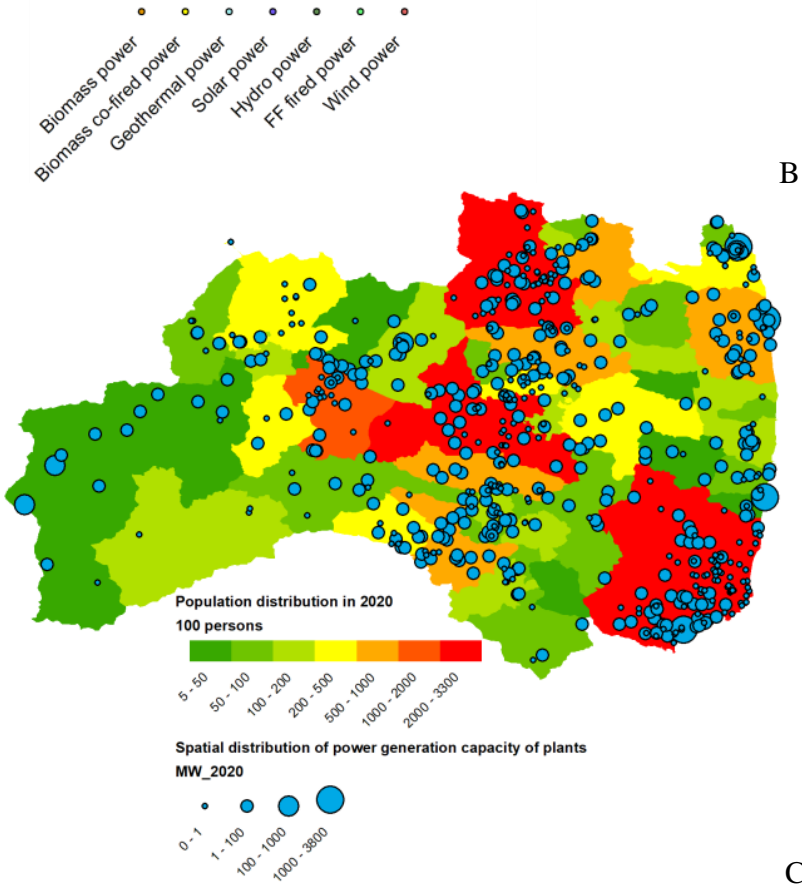

B

Figure 4 . The condition of the electricity supply in 2020 , Fukushima Prefecture: (A), the proportion of the total generation capacity by facility types (unit: MW and \%).

Biomass co-fired power plants were classified as FF power; (B), the spatial distribution of the generation capacity of power plants (625). The sizes of dots reflect the capacity of plants and the green dot with a red star inside shows the plant with the largest capacity; (C), the spatial distribution of the power generation capacity (MW) of plants and the population by municipalities in 2020

\subsection{The development on power generation before and after the GEJE}

To clearly show the development of power generation before and after the GEJE, we summarized the gridded differences in the power generation capacity between 2020 and 2010 with a 1 $\times 1 \mathrm{~km}$ resolution mesh (Figure 5). We could see that currently constructed power facilities with larger capacities mainly located on the eastern coastal areas (red grids) where were seriously damaged by the GEJE. In the middle areas, the number of grids is more than the eastern areas where power facilities are with lower capacities. Meanwhile, there have been almost no power facilities constructed in the western areas since the GEJE, where belongs to low population density areas. This is caused by some population intensive areas located in the middle of Fukushima, with more solar power facilities constructed. It reflects a trend that the increased numbers of power facilities mainly concentrated in the population intensive areas in Fukushima prefecture since the GEJE.

$$
\begin{aligned}
& \text { Power generation capacity gap_2020-2010 } \\
& \text { MW/cell }
\end{aligned}
$$

Figure 5. The map on the development of the generation capacity of power facilities since the GEJE. The gap is made by using the total gridded capacities of power generation facilities in 2020 minus that in 2010. Unit: MW cell ${ }^{-1}$

\section{RESULT AND DISCUSSIONS}

\subsection{Result}

As listed on the Table 1, we found that the number of solar power facilities increased significantly since 2010 (before the GEJE), and the electricity generation capacity of biomass cofired power plant increased mostly. As the shutdown of the nuclear power plants and the increased concern on the global warming, some biomass co-fired plants were constructed to meet the demand of electricity, rather than increasing the number of FF power plants. The significantly increased facility number and total capacity of solar power reflects the high development of renewable energy in Fukushima Prefecture. To show the promotion condition of the FIT scheme in Fukushima after the GEJE, we summarized the annual total capacities of renewable energy facilities in operation in Fukushima certificated by the FIT scheme from 2012 to the end of 2019 (FIT, 2020). 


\begin{tabular}{|c|c|c|c|c|}
\hline $\begin{array}{l}\text { Facility } \\
\text { type }\end{array}$ & $\begin{array}{l}\text { Facility } \\
\text { number } \\
\text { in } 2010\end{array}$ & $\begin{array}{l}\text { Facility } \\
\text { number } \\
\text { in } 2020\end{array}$ & $\begin{array}{l}\text { Total } \\
\text { capacity } \\
\text { in } 2010\end{array}$ & $\begin{array}{l}\text { Total } \\
\text { capacity } \\
\text { in } 2020\end{array}$ \\
\hline $\begin{array}{l}\text { Biomass } \\
\text { power }\end{array}$ & 6 & 12 & 78 & 84 \\
\hline $\begin{array}{l}\text { Biomass } \\
\text { co-fired }\end{array}$ & 8 & 11 & 1,638 & 3,827 \\
\hline Geothermal & 1 & 2 & 65 & 65 \\
\hline $\begin{array}{l}\text { Solar } \\
\text { power }\end{array}$ & 89 & 457 & 4 & 1,356 \\
\hline $\begin{array}{l}\text { Hydro } \\
\text { power }\end{array}$ & 95 & 107 & 1,950 & 1,953 \\
\hline $\begin{array}{l}\text { Wind } \\
\text { power }\end{array}$ & 29 & 33 & 116 & 170 \\
\hline FF power & 3 & 3 & 5,856 & 5,856 \\
\hline $\begin{array}{l}\text { Nuclear } \\
\text { power }\end{array}$ & 2 & 0 & 9,096 & 0 \\
\hline Total & 231 & 625 & 18,803 & 13,311 \\
\hline
\end{tabular}

Table 1 . The condition of the electricity supply facilities in 2010 and 2020, unit: MW

As shown in Figure 6A, the capacities of solar power facilities certificated by FIT scheme have increased sharply in this period, which is consistent with the trend for solar power indicated above (Table 1). The total capacity of all facilities increased from $17 \mathrm{MW}$ in 2012 to $1,700 \mathrm{MW}$ in 2019 , which gives the evidence on the development of renewable energy in Fukushima. The spatial distribution on the change of total generation capacity by FIT scheme from 2014 to 2020 is shown in Figure $6 \mathrm{~B}$. There is a significant development on the renewable energy in the middle and eastern areas of Fukushima which is consistent with the trend shown in Figure 5.

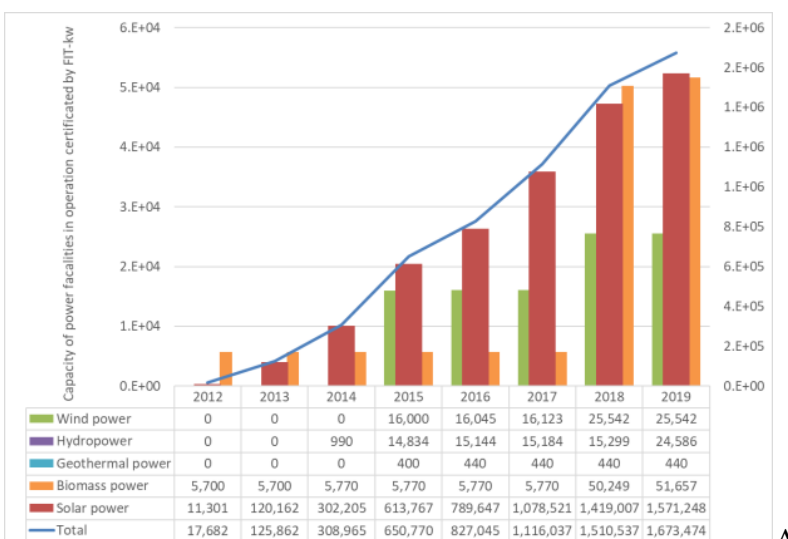

A

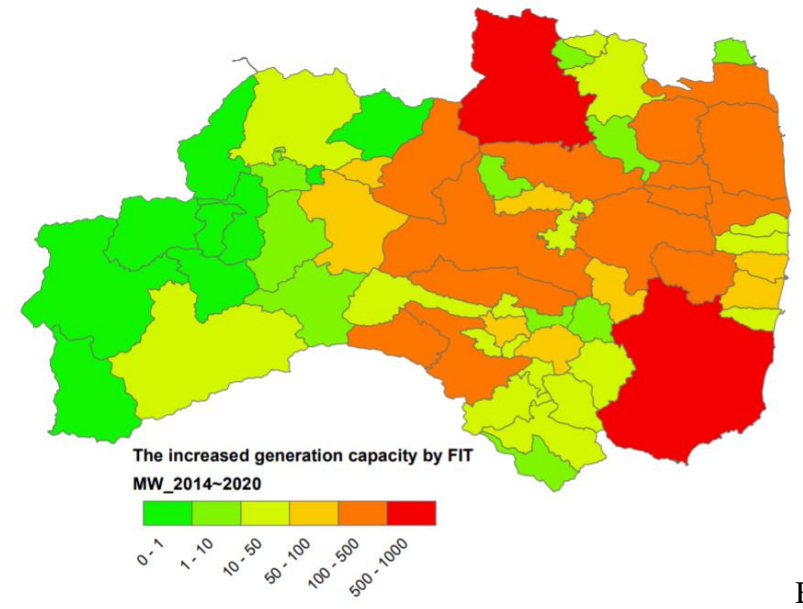

Figure 6 . The renewable energy facilities certificated by FIT scheme on: (A), the trend of annual total capacities of plants from 2012 to 2019. The capacities for solar power and the total refer to the right $y$-axis and those for the rest facilities refer to the left y-axis, unit: kw; (B), spatial variation of total capacities at a municipality level from 2014 to 2020, unit: MW

\subsection{Discussions}

The operating ratio is the ratio of the total electricity produced by the plant during a period of time compared to the total potential electricity that could be produced if the plant operated at 100 percent in the period. As the information reported by the government (Fukushima Prefecture, 2019; Agency for Natural Resources and Energy, 2019), we listed the indicators related to the energy supply and consumption before and after the GEJE on Table 2. The spatial coverage ratios were calculated based on the numbers of cells owning energy supply facilities in both years and the total number of cells from Figure 5. Based on the annual total supply of electricity (MWh) and the total capacity of power facilities (MW) for different years, we derived the needed operating ratio for current power facilities to judge whether their power supply was enough or not for the demand. The mean operating ratio of solar power is the lowest of all kinds of renewable facilities which was reported about $13.4 \%$ by the government (METI, 2016). It implies that the needed operating ratio of power facilities is reasonable to be achieved so as to meet the demand of electricity, which demonstrated the energy resilience in Fukushima Prefecture was enough in 2020.

\begin{tabular}{|l|l|l|}
\hline Indicator & $\begin{array}{l}\text { Before the GEJE } \\
(2010)\end{array}$ & $\begin{array}{l}\text { After the GEJE } \\
(2019)\end{array}$ \\
\hline $\begin{array}{l}\text { The population } \\
\text { The total supply } \\
\text { of electricity } \\
\text { (MWh) }\end{array}$ & $\begin{array}{l}2,029,064 \\
18,958,043\end{array}$ & $\begin{array}{l}1,844,173 \\
14,986,902\end{array}$ \\
$\begin{array}{l}\text { The total capacity } \\
\text { of power } \\
\text { facilities (MW) } \\
\text { The spatial } \\
\text { coverage ratio of } \\
\text { cells with energy } \\
\text { supply facilities } \\
\text { The needed } \\
\text { operating ratio of } \\
\text { power facilities }\end{array}$ & 18,803 & $3.7 \%$ \\
\hline
\end{tabular}

Table 2. The indicators related to the energy supply and consumption in Fukushima Prefecture before and after the GEJE

As reported by IEA, the energy conversion efficiency for power generation is about 35 37\%, which means about two third of energy used for power generation will be lost. Moreover, the energy conversion efficiency of FF power $(40 \%)$ is lower than that of the renewable power (51\%) and bioenergy (77\%) (IEA, 2009). It implies that increasing the renewable power is helpful for decreasing the energy loss so as to save more energy. Renewable energy is endless, requires less maintenance and operating costs, and owns more health and environmental benefits (emits less GHGs and pollutants). Thus, promoting the development of renewable energy e.g. FIT scheme is critical for the unban energy resilience.

This approach could help the policy makers spatial-explicitly identify the major energy supply facilities with high development, quantify the increased total generation capacity of them, and clarify the temporal variation on the total generation capacity of these facilities even in a local area. It could also help to explore the reasons for these development and the potential 
areas for future development of renewable energy, when combing our results with the regional specific maps e.g., wind speed map, solar radiation map, geothermal density map, and forest growth rate map. We believe this approach could contribute to the entire energy sector of Japan and its sustainable development policies.

\section{CONCLUSIONS}

In this study, we collected the data on power facilities before and after the GEJE, showed the spatial distribution of these facilities, and analysed the energy resilience and the trend on the development of energy system in Fukushima Prefecture.

We concluded that the nuclear power was major power supplier before the GEJE, and only a few renewable energy facilities existed at that time. The capacities of hydropower and biomass co-fired facilities accounted for the high proportion of all the renewable energy.

After the GEJE, the structure of power system was transformed from nuclear-reliant type to a distributed power type.

Up to now, the numbers and total capacity of renewable energy facilities increased significantly comparing to that before the GEJE, especially for the solar power.

The evidences showed that the energy resilience in Fukushima Prefecture was developed enough so as to face the risk from the future disaster and extreme climate events.

The FIT scheme was well promoted in Fukushima that was demonstrated making its energy system more resilient. Thus, this kind of energy policy should be highlighted which is useful for policy makers to enhance the energy resilience.

\section{ACKNOWLEDGEMENTS}

This research was performed by the Environment Research and Technology Development Fund (JPMEERF20191002) of the Environmental Restoration and Conservation Agency of Japan.

\section{REFERENCES}

Agency for Natural Resources and Energy, 2012. The introduction on the FIT scheme for renewable energy, https://www.enecho.meti.go.jp/category/saving_and_new/saien e/kaitori/surcharge.html (1July2020).

Agency for Natural Resources and Energy, 2019. The investigation reports on electricity supply, https://www.enecho.meti.go.jp/statistics/electric_power/ep002/r esults_archive.html (1July2020).

Arab, A., Khodaei, A., Khator, S.K., Han, Z., 2016. Electric Power Grid Restoration Considering Disaster Economics. IEEE Access, 4, 639-649.

Aruga, K., 2020. Analyzing the condition of Japanese electricity cost linkages by fossil fuel sources after the Fukushima disaster. Energy Transit., 4, 91-100, https://doi.org/10.1007/ s41825-020-00025-y.

Electrical Japan, 2020. The databases of power plants in Japan, http://agora.ex.nii.ac.jp/earthquake/201103-

eastjapan/energy/electrical-japan/area/07.html.ja (1May2020).
FIT, 2020. The website for FIT applications, https://www.fitportal.go.jp/servlet/servlet.FileDownload?retURL=\%2Fapex $\% 2$ FPublicInfo\&file=00P0K00001n1eNUUAY (1July2020).

Fukushima Prefecture, 2013. The renewable energy promotion vision in Fukushima Prefecture, https://www.pref.fukushima.lg.jp/site/portal/energy56.html (1June2020).

Fukushima Prefecture, 2019. The location, population, area of Fukushima Prefecture in 2019, https://www.pref.fukushima.lg.jp/site/ken-no-sugata/ichijinko.html (1June2020).

Hughes, L., de Jong, M., Wang, X., 2016. A generic method for analyzing the risks to energy systems. Applied Energy, 180, 895-908.

IEA, 2009. Co-Generation and District Energy, IEA, Paris https://www.iea.org/reports/co-generation-and-district-energy (1July2020).

Ministry of Economy, Trade and Industry (METI), 2016. The cost of solar and wind power (in Japanese), https://www.meti.go.jp/shingikai/santeii/pdf/027_s01_00.pdf.

METI, 2020. Energy white paper for 2019 (in Japanese), https://www.enecho.meti.go.jp/about/

whitepaper/2020html/2-1-4.html (1July2020).

Molyneaux, L., Brown, C., Wagner, L., Foster, J., 2016.

Measuring resilience in energy systems: Insights from a range of disciplines. Renew. Sust. Energ. Rev., 59, 1068-1079.

Sharifi, A., Yamagata, Y., 2016. Principles and criteria for assessing urban energy resilience: A literature review. Renew. Sustain. Energy Rev., 60, 1654-1677.

Taghizadeh-Hesary, F., Yoshino, N., Rasoulinezhad, E., 2017. Impact of the Fukushima nuclear disaster on the oil-consuming sectors of Japan. J. Comp. Asian Dev., 16(2), 113-134.

Wang, Q., M'Ikiugu, M. M., Kinoshita, I., 2014. A GIS-based approach in support of spatial planning for renewable energy: A case study of Fukushima, Japan. Sustainability, 6(4), 2087-2117.

Zhang, H., Yuan, H., Li, G., Lin, Y., 2018. Quantitative Resilience Assessment under a Tri-Stage Framework for Power Systems. Energies, 11, 1427. 